\title{
ANALISIS HASIL UJI KOMPETENSI DI LEMBAGA SERTIFIKASI PROFESI OTOMOTIF INDONESIA SE-DAERAH ISTIMEWA YOGYAKARTA TAHUN 2017
}

\author{
Rendra Ananta Prima Hardiyanta*1 \& Moch. Solikin ${ }^{1}$ \\ Fakultas Teknik Universitas Negeri Yogyakarta. \\ *E-mail:rendra.ananta@student.uny.ac.id
}

\begin{abstract}
Abstrak
Penelitian ini bertujuan : (1) mengetahui hasil uji kompetensi peserta uji kompetensi di Lembaga Sertifikasi Profesi (LSP) Otomotif Indonesia dari Daerah Istimewa Yogyakarta (DIY) pada tahun 2017 jika ditinjau dari skema sertifikasi dan (2) mengetahui sebaran unit kompetensi peserta uji kompetensi yang menyebabkan peserta uji kompetensi dinyatakan belum kompeten di LSP Otomotif Indonesia dari DIY pada tahun 2017. Penelitian ini merupakan penelitian deskriptif. Subjek penelitian ini adalah 198 peserta uji kompetensi. Teknik pengambilan data pada penelitian ini adalah dokumentasi. Penelitian ini menggunakan teknik analisis kuantitatif. Hasil penelitian menunjukan : (1) hasil uji kompetensi peserta uji kompetensi dari Daerah Istimewa Yogyakarta di LSP Otomotif Indonesia pada Tahun 2017 jika ditinjau berdasarkan skema 01 (Service \& Pemeliharaan 5000 KM Sepeda Motor) sebanyak 70\% (70) peserta dinyatakan kompeten dan 30\% (30) peserta dinyatakan belum kompeten (tinggi), pada skema 02 (Servis dan Pemeliharaan 10.000 Km Kendaraan Ringan Konvensional) sebanyak 75\% (15) peserta dinyatakan kompeten dan 25\% (5) dinyatakan belum kompeten (tinggi), dan pada skema 03 (Servis dan Pemeliharaan $10.000 \mathrm{Km}$ Kendaraan Ringan Sistim Injeksi) sebanyak 61,54\% (48) peserta dinyatakan kompeten dan 38,46\% (30) dinyatakan belum kompeten (sangat rendah), (2) sebaran unit kompetensi peserta uji kompetensi menunjukan pada skema 01 unit kompetensi yang pesertanya paling banyak belum kompeten adalah OTO.SM02.001.01 (Memelihara Engine berikut Komponen-komponennya) yaitu sebesar 73,33\%, pada skema 02 yaitu OTO.KR02.014.01 (Memelihara/Servis Sistem Bahan Bakar Bensin) dan OTO.KR05.011.01 (Memperbaiki Sistem Pengapian) yaitu sama-sama sebesar 100\%, sedangkan pada skema 03 yaitu OTO.KR05.012.01 (Memelihara / Servis dan Memperbaiki Engine Manajemen sistem) yaitu sebesar $76,67 \%$.
\end{abstract}

Kata kunci: Analisis, Hasil Uji kompetensi, Sebaran Unit Kompetensi

\section{ANALYSIS OF COMPETENCE TEST RESULT IN INDONESIAN AUTOMOTIVE PROFESSION CERTIFICATION BODY REGION OF YOGYAKARTA IN 2017}

\begin{abstract}
This study aims to: (1) know competence test results of competency test participants in the Indonesian Automotive Profession Certification Body from Yogyakarta Special Region (DIY) in 2017 if reviewed from the certification scheme and (2) to know the distribution of competency unit of competency test participants causing competency test participants to be declared not yet competent in LSP Otomotif Indonesia from DIY in 2017 This research is a descriptive research. The subject in this research is 198 competency test participants. Technique of collecting data is documentation. This research uses quantitative analysis technique. The result of the research shows that: (1) the competency test results of
\end{abstract}


competency test participants from the Special Region of Yogyakarta in Indonesian Automotive Profession Certification Body in 2017 if reviewed based on scheme 01 (Service \& Maintenance 5000 KM Motorcycles) is 70\% (70) participants are declared competent and $30 \%$ (30) participants are deemed incompetent (including high category). Furthermore, in scheme 02 (Service and Maintenance 10,000 Km of Conventional Light Vehicles) $75 \%$ (15) are competent and 25\% (5) declared incompetent (including category and in scheme 03 (Service and Maintenance of 10,000 Km Light Vehicle Injection System) of 61.54\% (48) participants are declared competent and $38.46 \%$ (30) declared not yet competent (including very low category), (2) the distribution of competency units shows that in scheme 01, competency unit that most competent participant is OTO.SM02.001.01 (Maintaining Engine with its Components) that is equal to $73.33 \%$, in the scheme of 02 competency units that most participants are not competent are OTO.KR02.014.01 (Maintenance / Service of Gasoline Fuel System) and OTO.KR05.011.01 (Fixing Ignition System) that is equal to 100\%, whereas in the scheme of 03 competency unit that most participants are not competent is OTO.KR05.012.01 (Maintaining / Servicing and Improving Engine Management system) that is equal to $76.67 \%$.

Keywords: Analysis, Competency Test Results, Distribution of Competency Unit

\section{PENDAHULUAN}

Daya saing Indonesia secara global menurut Global Competitiveness Index tahun 2018 menempati peringkat ke-36 dari 137 negara dunia. Berdasarkan survey Institut Européen d'Administration des Affaires (INSEAD), Global Talent Competitivenes Index tahun 2018, Indonesia berada di peringkat 88 dari 119 negara dalam hal keahlian di tingkat mid-level skills (vokasi). Indikator produktivitas tenaga kerja dan ketersediaan teknisi serta associate professionals memiliki peringkat yang rendah (peringkat 75 \& 94). Hal ini menunjukan bahwa mayoritas lulusan pendidikan vokasional justru menempati posisi low level. Berdasarkan data BPS, Sakernas Bulan Agustus tahun 2016, menunjukan pengangguran terbuka di Daerah Istimewa Yogyakarta (DIY) sebanyak 26.202 orang merupakan pengangguran berasal dari SMTA Kejuruan. Salah satu cara untuk penjamin kualitas SDM adalah dengan adanya sertifikasi kompetensi kerja oleh Lembaga Sertifikasi Profesi berlisensi BNSP menurut Standar Kualifikasi Kerja Nasional Indonesia (SKKNI). Pada lembaga pendidikan terdapat kesenjangan materi yang diajarkan. Sebagai contoh hasil penelitian Wijanarka, B.S. (2008) menyebutkan bahwa kompetensi proses pemesinan yang diajarakan di Jurusan Pendidikan Teknik Mesin belum memenuhi semua standar kompetensi NIMS. Lembaga Sertifikasi Profesi (LSP) merupakan lembaga yang berperan meminimalkan kesenjangan kompetensi yang diajarkan dengan standar kebutuhan di dunia industri dengan 
cara menyusun skema sertifikasi dan menyampaikan unit kompetensi yang dibutuhkan industri serta sesuai dengan standar.

Selanjutnya berdasarkan data website direktoritraining.com per tanggal 4 Mei 2018, di Indoneisa terdapat tiga LSP-P3 dari bidang teknisi otomotif yaitu: (1) LSP Teknisi Otomotif Indoneisa (LSP-TO), (2) LSP Teknisi Otomotif Profesional Indonesia (LSP-TOP) dan LSP Otomotif Indonesia (LSP Oto-Ina). Satu-satunya LSP-P3 berlisensi BNSP yang melakukan tugas sertifikasi kompetensi bidang otomotif dan berarada di Daerah Istimewa Yogyakarta adalah LSP Otomotif Indonesia. Pembentukan LSP Otomotif Indonesia tidak lepas dari upaya untuk membantu pemerintah dalam mempersiapkan sumber daya manusia yang berkualitas melalui uji kompetensi. Sehingga sertifikasi kompetensi kerja dan uji kompetensi menjadi sangat penting.

Penelusuran lebih lanjut masalah dapat diidentifikasi yaitu: (1) kualitas Sumber Daya Manusia (SDM) di Indonesia belum optimal dan perlu ditingkatkan lagi, daya saing Indonesia secara global Global Competitiveness Index tahun 2017-2018 menempati peringkat ke-36 dari 137 negara dunia, (2) tingkat pengangguran lulusan SMK masih tinggi, tercatat per Agustus 2017 pengangguran lulusan SMK mencapai 11,41\% dari 7,04 juta orang dan sebanyak 26.202 orang berada di DIY dengan tingkat pengangguran 5,76, (3) Pada tahun 2017 jumlah peserta dari DIY yang lulus uji kompetensi di LSP-P3 LSP Otomotif Indonesia belum mencapai $100 \%$ yaitu baru mencapai 67,17\% (133) dan berada di bawah peserta yang berasal dari luar DIY yaitu sebesar 81,37\% (176). Selama ini LSP Otomotif Indonesia belum mengidentifikasi hasil uji menurut skema sertifikasi dan sebaran unit kompetensi yang menyebabkan peserta uji kompetensi dinyatakan belum komepten sebagai bahan menyusun rencana strategis bagi LSP dan bahan evaluasi kepada lembaga pendidikan dan pelatihan.

Penelitian ini bertujuan untuk mengetahui gambaran hasil uji kompetensi ditinjau dari skema sertifikasi dan sebaran unit kompetensi yang menyebabkan peserta dinyatakan belum kompeten sehingga dapat memberikan gambaran kepada asesor kompetensi, lembaga pendidikan dan pelatihan, lembaga sertifikasi profesi, maupun peneliti pada umumnya mengenai pelaksanaan, hasil, dan sebaran unit kompetensi sehingga dapat dijadikan bahan evaluasi.

\section{METODE PENELITIAN}

Penelitian ini merupakan penelitian deskriptif dengan menggunakan pendekatan kuantitatif. Penelitian ini dilaksanakan pada tanggal 23 Maret 2018 hingga 2 Mei 2018 di 
Lembaga Sertifikasi Profesi Otomotif Indonesia yang terletak di Jalan Kyai Mojo Nomor 70, Kantor BLPT Yogyakarta. Subjek dalam penelitian ini adalah seluruh peserta uji kompetensi dari DIY yang mengikuti uji kompetensi di LSP Otomotif Indonesia pada tahun 2017 yaitu sejumlah 198 peserta.

Data dalam penelitian ini merupakan data sekunder yang diambil dengan Instrumen pengumpulan data yang dikembangkan peneliti berupa lembar hasil uji kompetensi dan lembar hasil sebaran unit kompetensi. Sedangkan pengolahan data dalam penelitian ini menggunakan teknik analisis kuantitatif yaitu: (1) penjumlahan, (2) rata-rata, (3) tabel distribusi frekuensi, (4) standar deviasi, (5) distribusi kecencerungan, dan (6) klasifikasi kecenderungan mengacu pada tabel klasifikasi kecenderungan (Djemari Mardapi, 2008:123) berikut ini.

Tabel 1. Klasifikasi Kecenderungan

\begin{tabular}{ccc}
\hline Hasil Uji Kompetensi & Persentase (\%) & Klasifikasi \\
\hline$X>(M+1 \cdot S D)$ & $X>75,64$ & Sangat tinggi \\
$(M+1 \cdot S D)>X \geq M$ & $75,64>X \geq 68,84$ & Tinggi \\
$M>X \geq(M-1 \cdot S D)$ & $68,84>X \geq 62,04$ & Rendah \\
$X<(M-1 \cdot S D)$ & $X<62,04$ & Sangat Rendah \\
\hline
\end{tabular}

\section{HASIL PENELITIAN DAN PEMBAHASAN}

Hasil uji kompetensi dapat dilihat pada tabel di bawah ini.

Tabel 2. Distribusi Frekuensi Keputusan Akhir Hasil Pelaksanaan Uji Kompetensi LSP Otomotif Indonesia 198 Peserta dari DIY Tahun 2017

\begin{tabular}{ccc}
\hline \multirow{2}{*}{$\begin{array}{c}\text { Jumlah Peserta Uji } \\
\text { Kompetensi }\end{array}$} & \multicolumn{2}{c}{ Keputusan Akhir } \\
\cline { 2 - 3 } & Kompeten & Belum Kompeten \\
\hline $\mathbf{1 9 8}$ & $67,17 \%(133)$ & $32,83 \%(65)$ \\
\hline
\end{tabular}

Selanjutnya dibuat tabel untuk mengetahui jumlah peserta yang kompeten dan belum kompeten, serta tingkat kelulusan untuk masing-masing skema sertifikasi sehingga dapat disajikan dalam tabel berikut ini.

Tabel 3. Distribusi Frekuensi Hasil Pelaksanaan Uji Kompetensi LSP Otomotif Indonesia 198 Peserta dari DIY Tahun 2017 yang Dinyatakan Kompeten dan Belum Kompeten

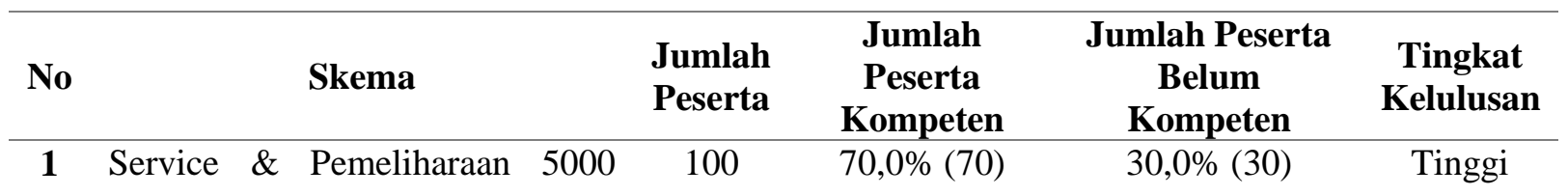




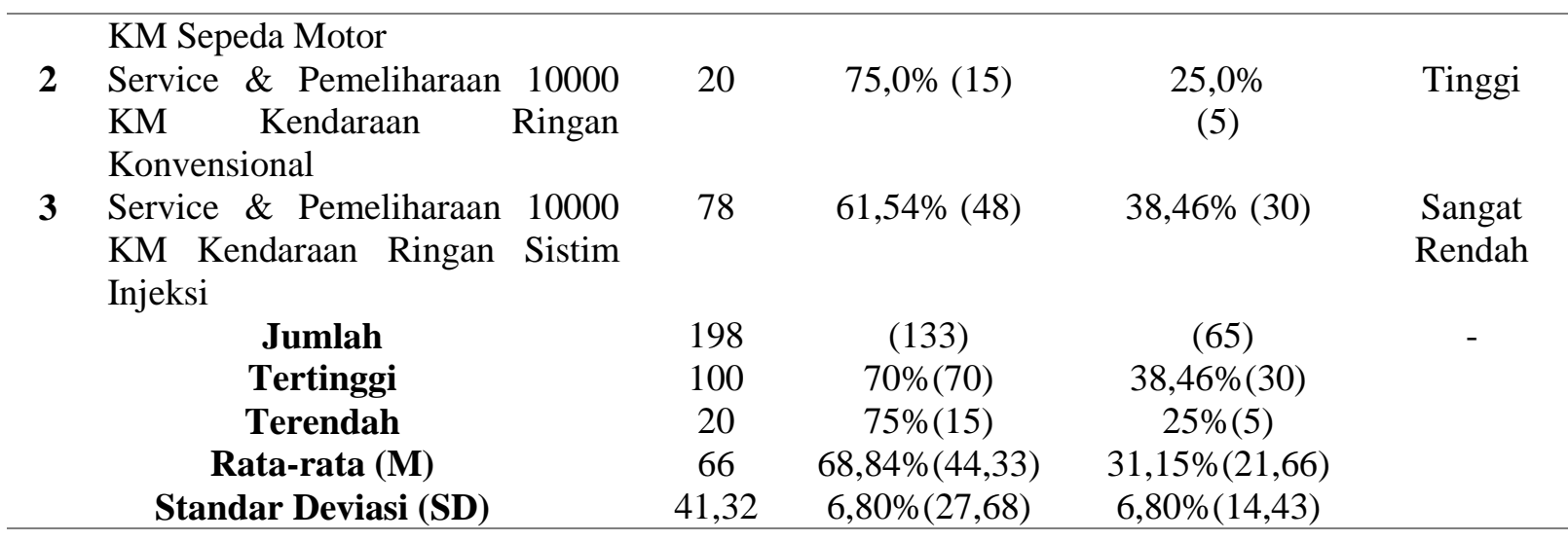

Sebagaimana pendapat Dobson (2003:62) menyatakan tentang kompetensi. “... the ability to peform tasks and duties to the standard expected in employement" Hal ini menunjukan bahwa pada skema 01 sebanyak $70 \%$ (70) peserta uji kompetensi dapat meunjukan kemampuannya dalam melaksanakan tasks (tugas-tugas) dan duties (pekerjaan) sesuai dengan standar yang diharapkan dalam pekerjaan servis dan pemeliharaan $5.000 \mathrm{KM}$ Sepeda Motor Karburator. Pada skema 02 Sebanyak 75\% (15) peserta dapat menunjukan kemampuannya kepada asesor kompetensi untuk melaksanakan pekerjaan servis dan pemeliharaan 10.000 KM Kendaraan Ringan Konvensional. Selanjutnya pada skema 03 sebanyak $61,04 \%$ (48) peserta dapat melaksanakan pekerjaan servis dan peneliharaan 10.000 KM Kendaraan Ringan Sistim Injeksi.

Berdasarkan data tersebut dapat digambarkan bahwa sebanyak 133 peserta uji yang dinyatakan kompeten dapat menunjukan kemampuannya yang mencakup aspek pengetahuan, ketrampilan, dan sikap kerja sesuai dengan standar yang telah ditetapkan SKKNI. Sebaliknya, 65 peserta uji yang dinyatakan belum kompeten berarti belum dapat menunjukan kemampuan dalam aspek pengetahuan, keterampilan dan sikap kerja yang sesuai dengan standar yang telah ditetapkan.

Peserta yang dinyatakan belum kompeten tidak diberikan sertifikat dari BNSP namun diberikan logsheet yang menunjukan bahwa dirinya belum dapat memenuhi seluruh persyaratan untuk mendapatkan sertifikat kompetensi dari BNSP. Logsheet memiliki bentuk yang mirip dengan sertifikat kompetensi dari BNSP namun berisi unit-unit kompetensi yang telah dikuasai dan yang belum dikuasai.

Selanjutnya distribusi sebaran unit kompetensi pada skema 01 Service \& Pemeliharaan 5000 KM Sepeda Motor peserta uji kompetensi dapat dilihat pada tabel di bawah ini. 
Tabel 4. Distribusi Frekensi Sebaran Unit Kompetensi 30 Peserta Uji Kompetensi pada Skema 01 Service \& Pemeliharaan 5000 KM Sepeda Motor di Lembaga Sertifikasi Profesi Otomotif Indonesia Tahun 2017

\begin{tabular}{|c|c|c|c|}
\hline \multirow[b]{2}{*}{ No } & \multirow[b]{2}{*}{ Unit Kompetensi } & \multicolumn{2}{|c|}{ Keputusan Akhir } \\
\hline & & $\begin{array}{l}\text { Belum } \\
\text { Kompeten }\end{array}$ & $\begin{array}{l}\text { Belum } \\
\text { Kompeten } \\
(\%)\end{array}$ \\
\hline 1 & $\begin{array}{lrrr}\text { OTO.SM01.001.01 } & \text { (Mengikuti } & \text { Prosedur } & \text { Keselamatan, } \\
\text { Kesehatan Kerja, dan Lingkungan) } & & \end{array}$ & 1 & 3.33 \\
\hline 2 & OTO.SM01.002.01 (Membaca dan Memahami Gambar Teknik) & 7 & 23.33 \\
\hline 3 & $\begin{array}{l}\text { OTO.SM01.003.01 (Menggunakan dan Memelihara Peralatan } \\
\text { dan Perlengkapan di Tempat Kerja) }\end{array}$ & 12 & 40.00 \\
\hline 4 & OTO.SM01.006.01 (Menggunakan dan Memelihara Alat Ukur) & 12 & 40.00 \\
\hline 5 & $\begin{array}{l}\text { OTO.SM02.001.01 (Memelihara Engine berikut Komponen- } \\
\text { Komponennya) }\end{array}$ & 22 & 73.33 \\
\hline 6 & $\begin{array}{l}\text { OTO.SM02.004.01 (Memelihara Sistem Pendingin berikut } \\
\text { Komponen-komponennya) }\end{array}$ & 8 & 26.67 \\
\hline 7 & OTO.SM02.006.01 (Memelihara Sistem Bahan Bakar Bensin) & 10 & 33.33 \\
\hline 8 & $\begin{array}{l}\text { OTO.SM02.007.01 (Memperbaiki dan Melakukan Overhaul } \\
\text { Komponen Sistem Bahan Bakar Bensin) }\end{array}$ & 1 & 3.33 \\
\hline 9 & OTO.SM02.014.01 (Memelihara Sistem Rem) & 17 & 56.67 \\
\hline 10 & OTO.SM02.017.01 (Memeriksa Sistem Kemudi) & 8 & 26.67 \\
\hline 11 & OTO.SM02.022.01 (Melepas, Memasang, dan Menyetel Roda) & 10 & 33.33 \\
\hline 12 & OTO.SM02.024.01 (Memelihara Rantai/Chain) & 19 & 63.33 \\
\hline 13 & $\begin{array}{l}\text { OTO.SM02.026.01 (Menguji, Memelihara, dan Mengganti } \\
\text { Baterai) }\end{array}$ & 19 & 63.33 \\
\hline 14 & OTO.SM02.033.01 (Memperbaiki Sistem Pengapian) & 16 & 53.33 \\
\hline & Total & - & - \\
\hline & Nilai Tertinggi & 22 & 73,33 \\
\hline & Nilai Terendah & 1 & 3,33 \\
\hline & Rata-rata & 11,57 & 38,57 \\
\hline & Standar Deviasi & 6,46 & 21,55 \\
\hline
\end{tabular}

Berdasarkan Kepmen Tenaga Kerja dan Transmigrasi Nomor 116/MEN/VII/2004 tentang sub sektor kendaraan ringan dan 05/MEN/IV/2005 tentang sub sektor sepeda motor menunjukan bahwa sebanyak 73,33\% (22) peserta belum memiliki kompetensi untuk melaksanakan: (1) pemeliharaan engine berikut komponen-komponennya tanpa menyebabkan kerusakan terhadap komponen atau sistem lainnya, (2) mengakses dan memahami informasi engine yang benar dari spesifikasi pabrik, (3) melengkapi data yang tepat dilengkapi sesuai dengan hasil pemeriksaan, (4) melaksanakan pemeliharaan engine dilakukan sesuai dengan pedoman industri yang ditetapkan, (5) melaksanakan seluruh kegiatan pemeliharaan dilakukan berdasarkan SOP (Standard Operation Procedures), peraturan K3L (Keselamatan, Kesehatan Kerja, dan Lingkungan), dan prosedur/kebijakan perusahaan.

Berdasarkan lembar reportsheet yang termasuk dimensi kompetensi Taks Skill (TS) pada unit kompetensi OTO.SM02.001.01 antara lain: (1) melihat buku manual, (2) 
memeriksa celah katup, (3) menyetel celah katup, (4) menggunakan oli yang sesuai, (5) memeriksa tekanan kompresi, dan memeriksa momen baut pengikat knalpot. Pada dasarnya seluruh pekerjaan adalah mencakup dimensi kompetensi Taks Skill. Selanjutnya dimensi Taks Management Skill (TMS) adalah peserta uji kompetensi diharuskan menyelesaikan beberapa pekerjaan dalam satu waktu, waktu yang disediakan dibuat sedemikian rupa sehingga hanya cukup untuk mengerjakan pekerjaan yang diberikan. Jika peserta tidak dapat mengelola beberapa pekerjaan dalam waktu yang bersamaan maka peserta belum kompeten. Dimensi Contingency Management Skills (CMS) dilakukan dengan cara simulasi kejadian tidak lazim oleh asesor atau asesor memberikan pertanyaan kasus mengenai apa yang dilakukan peserta uji ketika jika ketika menyetel celah katup tiba-tiba rocker arm macet atau feeler gauge patah. Dimensi Job Role/Enviroment Skills (JRES) yaitu pada saat peserta uji melakukan pekerjaan dengan memperhatikan lingkungan kerja, standar kerja (spesifikasi teknis), atau Standard Operational Procedure (SOP) pekerjaan yang ada. Transfer Skills (TRS) diukur ketika peserta uji dapat melakukan pengukuran dengan menggunakan berbagai macam alat yang disediakan dan berbagai jenis kendaraan yang ada. Artinya, peserta uji dapat mentransfer kemampuannya kepada objek pekerjaan lain yang sejenis. Diagram sebaran unit kompetensi dapat dilihat pada gambar di bawah ini.

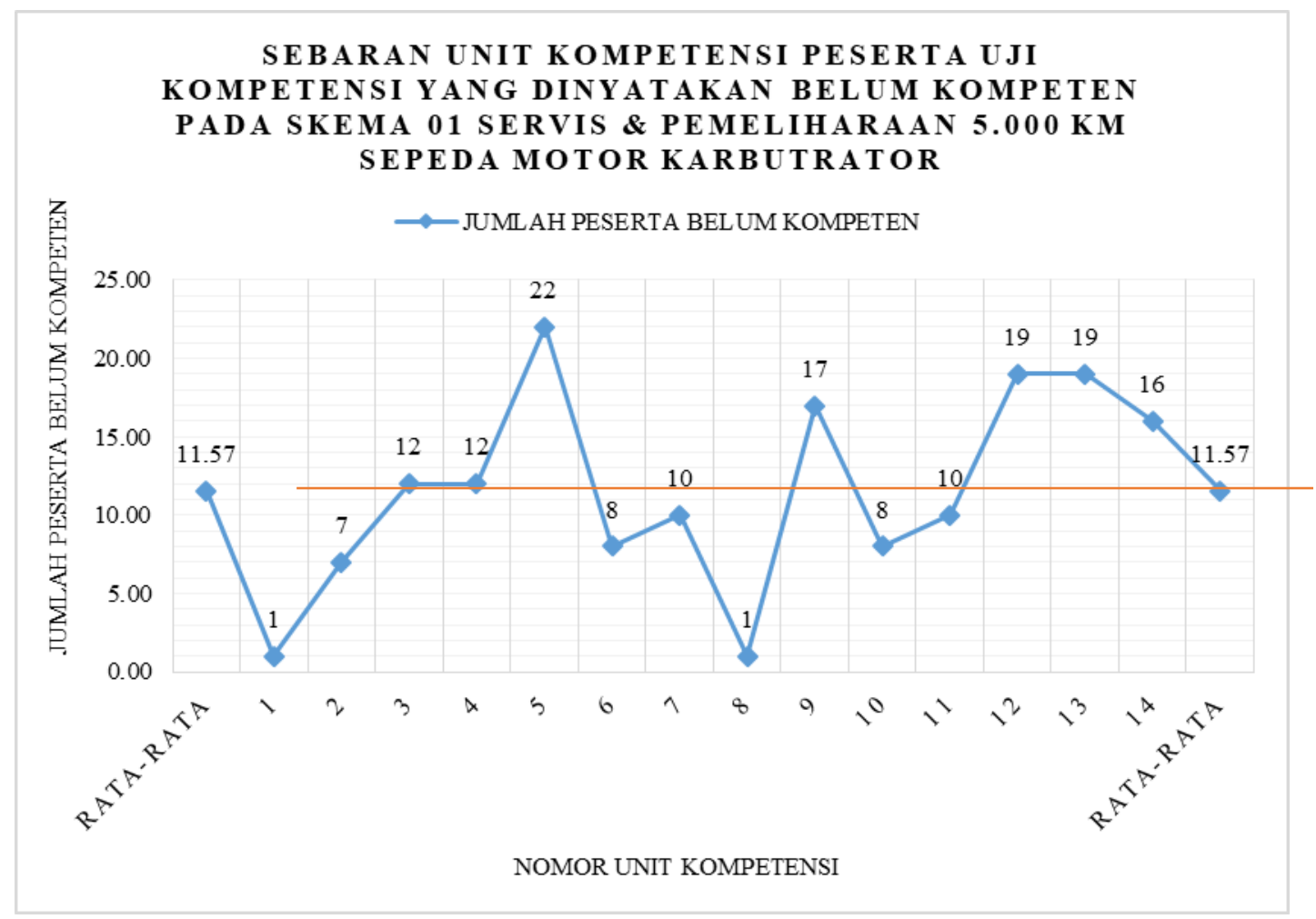

Gambar 1. Diagram Garis Sebaran Unit Kompetensi Peserta Uji Kompetensi yang Dinyatakan Belum Kompeten pada Skema 01 Servis dan Pemeliharaan 5.000 Km Sepeda

Motor Karburator 
Tabel 5. Distribusi Frekensi Sebaran Unit Kompetensi 5 Peserta Uji Kompetensi pada Skema 02 Servis dan Pemeliharaan $10.000 \mathrm{Km}$ Kendaraan Ringan Konvensional di Lembaga Sertifikasi Profesi Otomotif Indonesia Tahun 2017

\begin{tabular}{|c|c|c|c|}
\hline \multirow[b]{2}{*}{ No } & \multirow[b]{2}{*}{ Unit Kompetensi } & \multicolumn{2}{|c|}{ Keputusan Akhir } \\
\hline & & $\begin{array}{l}\text { Belum } \\
\text { Kompeten }\end{array}$ & $\begin{array}{c}\text { Belum } \\
\text { Kompeten } \\
(\%)\end{array}$ \\
\hline 1 & OTO.KR01.009.01 (Membaca dan Memahami Gambar Teknik) & 4 & 80 \\
\hline 2 & OTO.KR01.010.01 (Menggunakan dan Memelihara Alat Ukur) & 0 & 0 \\
\hline 3 & $\begin{array}{lllll}\text { OTO.KR01.016.01 (Mengikuti Prosedur } & \text { Kesehatan dan } \\
\text { Keselamatan kerja) } & & & & \end{array}$ & 0 & 0 \\
\hline 4 & $\begin{array}{l}\text { OTO.KR01.001.01 (Melaksanakan Pemeliharaan/Servis } \\
\text { Komponen) }\end{array}$ & 2 & 40 \\
\hline 5 & $\begin{array}{l}\text { OTO.KR01.017.01 (Menggunakan dan Memelihara Peralatan } \\
\text { dan Perlengkapan Tempat Kerja) }\end{array}$ & 0 & 0 \\
\hline 6 & OTO.KR01.018.01 (Kontribusi komunikasi di tempat kerja) & 0 & 0 \\
\hline 7 & $\begin{array}{l}\text { OTO.KR02.001.01 (Memelihara / Servis Engine dan Komponen- } \\
\text { komponennya) }\end{array}$ & 1 & 20 \\
\hline 8 & $\begin{array}{l}\text { OTO.KR02.010.01 (Memelihara/Servis Sistem Pendingin dan } \\
\text { Komponen-Komponennya) }\end{array}$ & 2 & 40 \\
\hline 9 & $\begin{array}{l}\text { OTO.KR02.014.01 (Memelihara/Servis Sistem Bahan Bakar } \\
\text { Bensin) }\end{array}$ & 5 & 100 \\
\hline 10 & OTO.KR02.020.01 (Memelihara/Servis Sistem Kontrol Emisi) & 4 & 80 \\
\hline 11 & $\begin{array}{l}\text { OTO.KR05.001.01 (Menguji, Memelihara/Servis dan Mengganti } \\
\text { Baterai) }\end{array}$ & 1 & 20 \\
\hline 12 & OTO.KR05.011.01 (Memperbaiki Sistem Pengapian & 5 & 100 \\
\hline & Total & - & - \\
\hline & Nilai Tertinggi & 5 & 100 \\
\hline & Nilai Terendah & 0 & 0 \\
\hline & Rata-rata & 2 & 40 \\
\hline & Standar Deviasi & 2 & 40 \\
\hline
\end{tabular}

Berdasarkan tabel di atas diketahui bahwa pada skema 02 (Servis dan Pemeliharaan 10.000 Km Kendaraan Ringan Konvensional) dari 12 unit kompetensi, unit kompetensi yang paling banyak dinyatakan belum kompeten adalah unit kompetensi dengan kode OTO.KR02.014.01 (Memelihara/Servis Sistem Bahan Bakar Bensin) dan OTO.KR05.011.01 (Memperbaiki Sistem Pengapian) yaitu sebesar 100\% (5).

Peserta tidak dapat menunjukan hasil yang sesuai dengan Kriteria Unjuk Kerja (KUK) yang dipersyaratkan. Sesuai dengan PBNSP bahwa jika terdapat satu unit kompetensi yang dinyatakan belum kompeten setelah proses asesmen berakhir, maka peserta uji kompetensi akan dinyatakan belum kompeten pada skema sertifikasi yang diambil yaitu skema 02 (Servis dan Pemeliharaan 10.000 Km Kendaraan Ringan Konvensional).

Menurut SKKNI KEPMEN Nomor 116 Tahun 2014 Tentang Sub Sektor Kendaraan Ringan sebanyak 100\% (5) peserta tidak dapat memelihara/servis sistem bahan bakar bensin meliputi: (1) memeliharaan/servis komponen/sistem bahan bakar bensin dilaksanakan tanpa 
menyebabkan kerusakan terhadap komponen atau sistem lainnya, (2) mengakses dan memahami informasi sistem bahan bakar yang benar dari spesifikasi pabrik, (3) memeliharaan/servis komponen/sistem bahan bakar bensin dilaksanakan berdasarkan spesifikasi pabrik, (4) melengkapi data yang tepat sesuai hasil pemeliharaan/servis, (5) melaksanakan seluruh kegiatan pemeliharaan/servis komponen sistem bahan bakar berdasarkan SOP (Standard Operation Procedures), undang-undang K3 (Keselamatan dan Kesehatan Kerja), peraturan perundangundangan dan prosedur/kebijakan perusahaan sehingga dinyatakan belum kompeten.

Sebanyak 100\% (5) peserta tidak dapat memperbaiki sistem pengapian meliputi: (1) memperbaiki sistem pengapian tanpa menyebabkan kerusakan terhadap komponen atau sistem lainnya, (2) mengakses dan memahami informasi sistem pengapian yang benar dari spesifikasi pabrik, (3) melaksanakan perbaikan, penyetelan dan penggantian komponen dengan menggunakan peralatan, tehnik dan material yang sesuai, (4) menguji dan mencatat sistem pengapian menurut prosedur dan kebijakan perusahaan, (5) melaksanakan seluruh kegiatan perbaikan dilaksanakan berdasarkan SOP (Standard Operation Procedures), undangundang K3 (Keselamatan dan Kesehatan Kerja), peraturan perundang-undangan dan prosedur/kebijakan perusahaan sehingga dinyatakan belum kompeten.

Berdasarkan lembar reportsheet yang termasuk dimensi kompetensi Taks Skill (TS) antara lain: (1) memeriksa saringan udara, (2) memeriksa kebocoran sistem bahan bakar, (3) memeriksa kondisi Platina, (4) memeriksa kondisi Condensator, (5) memeriksa kondisi Rotor, (6) memeriksa kondisi Cap Distributor, (7) memeriksa kondisi Shaft Distributor, (8) memeriksa kondisi Sentrifugal Advance, (9) memeriksa kondisi Vaccum Advance, (10) memeriksa kondisi busi, (11) memeriksa tahanan kabel busi, (12) memeriksa tahanan kabel Coil, (13) memeriksa tahanan primer dan sekunder coil, (14) memeriksa sudut $d w e l l$, dan (15) memeriksa sudut pengapian. Selanjutnya dimensi Taks Management Skill (TMS) diukur ketika peserta uji kompetensi diharuskan menyelesaikan beberapa pekerjaan dalam satu waktu, waktu yang disediakan dibuat sedemikian rupa sehingga hanya cukup untuk mengerjakan pekerjaan yang diberikan. Misalnya, memeriksa dan menyetel celah busi. Jika peserta tidak dapat mengelola beberapa pekerjaan dalam waktu yang bersamaan maka peserta belum kompeten. Dimensi Contingency Management Skills (CMS) dilakukan dengan cara simulasi kejadian tidak lazim oleh asesor seperti misalnya terjadi kebakaran atau asesor memberikan pertanyaan kasus mengenai apa yang dilakukan peserta uji ketika jika ketika memeriksa sudut pengapian tiba-tiba timming light mati atau kabel terputus. Dimensi Job Role/Enviroment Skills (JRES) yaitu pada saat peserta uji melakukan pekerjaan dengan 
memperhatikan lingkungan kerja, standar kerja (spesifikasi teknis), atau Standard Operational Procedure (SOP) pekerjaan yang ada. Transfer Skills (TRS) diukur ketika peserta uji dapat melakukan pengukuran dengan menggunakan berbagai macam alat yang disediakan dan berbagai jenis kendaraan yang ada. Artinya, peserta uji dapat mentransfer kemampuannya kepada objek pekerjaan lain yang sejenis. Diagram sebaran unit kompetensi dapat dilihat pada gambar di bawah ini.

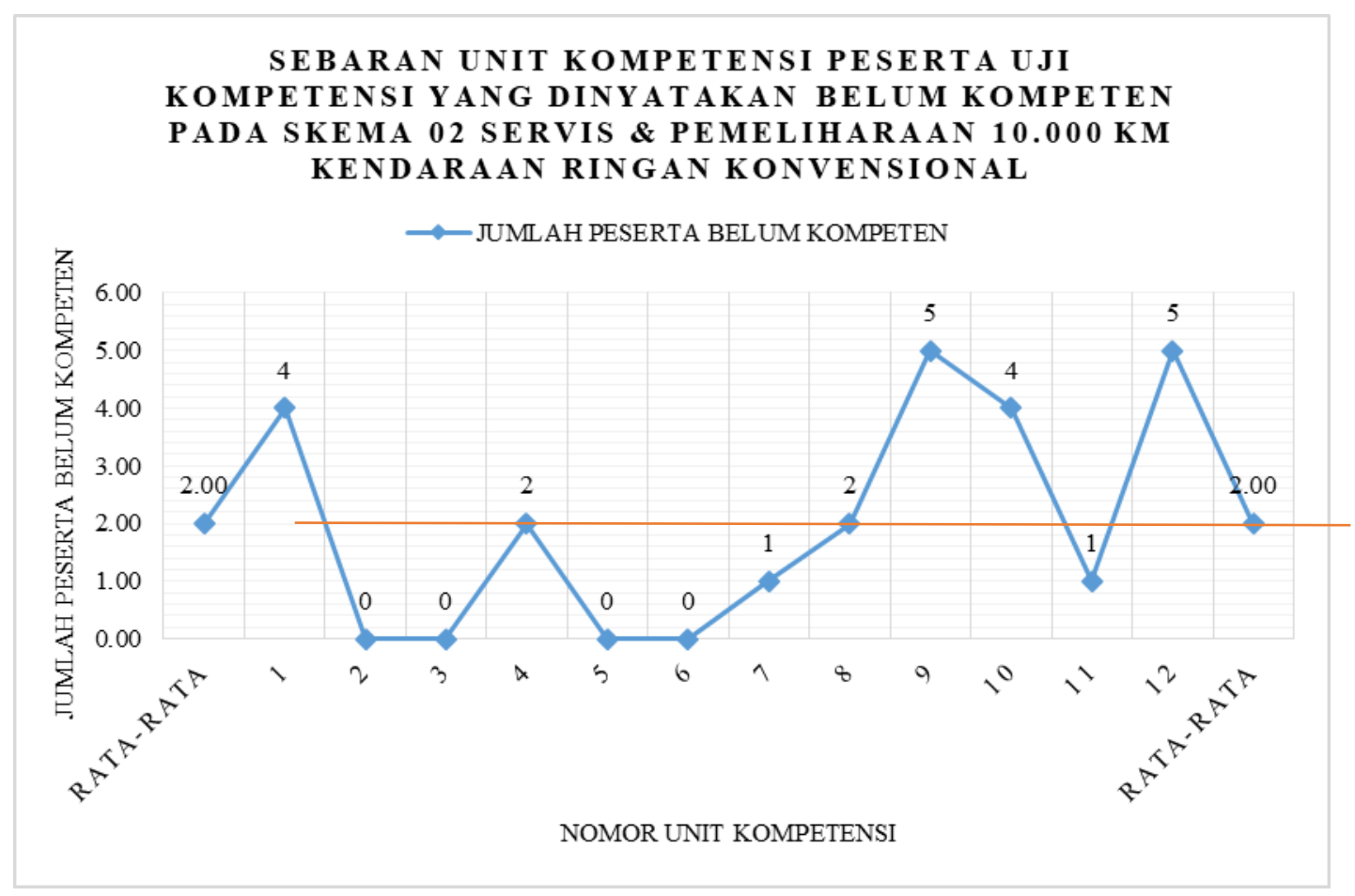

Gambar 2. Diagram Garis Sebaran Unit Kompetensi Peserta Uji Kompetensi yang Dinyatakan Belum Kompeten pada Skema 02 Servis dan Pemeliharaan 10.000 Km Kendaraan Ringan Konvensional

Tabel 7. Distribusi Frekensi Sebaran Unit Kompetensi 30 Peserta Uji Kompetensi pada Skema 03 Servis dan Pemeliharaan 10.000 Km Kendaraan Ringan Sistim Injeksi di Lembaga Sertifikasi Profesi Otomotif Indonesia Tahun 2017

\begin{tabular}{|c|c|c|c|}
\hline \multirow[b]{2}{*}{ No } & \multirow[b]{2}{*}{ Unit Kompetensi } & \multicolumn{2}{|c|}{ Keputusan Akhir } \\
\hline & & $\begin{array}{l}\text { Belum } \\
\text { Kompeten }\end{array}$ & $\begin{array}{l}\text { Belum } \\
\text { Kompeten } \\
(\%)\end{array}$ \\
\hline 1 & OTO.KR01.009.01 (Membaca dan Memahami Gambar Teknik) & 4 & 13.33 \\
\hline 2 & $\begin{array}{l}\text { OTO.KR01.017.01 (Menggunakan dan Memelihara Peralatan } \\
\text { dan Perlengkapan Tempat Kerja) }\end{array}$ & 4 & 13.33 \\
\hline 3 & $\begin{array}{lllll}\text { OTO.KR01.016.01 } & \text { (Mengikuti Prosedur } & \text { Kesehatan } & \text { dan } \\
\text { Keselamatan kerja) } & & & & \end{array}$ & 6 & 20.00 \\
\hline 4 & OTO.KR01.001.01 & 6 & 20.00 \\
\hline
\end{tabular}


Komponen)

5 OTO.KR01.018.01 (Kontribusi Komunikasi di Tempat Kerja)

6 OTO.KR02.001.01 (Memelihara / Servis Engine dan Komponenkomponennya)

7 OTO.KR02.014.01 (Memelihara/Servis Sistem Bahan Bakar Bensin)

8 OTO.KR05.001.01 (Menguji, Memelihara/Servis dan Mengganti Baterai)

9 OTO.KR01.010.01 (Menggunakan dan Memelihara Alat Ukur)

10 OTO.KR05.011.01 (Memperbaiki Sistem Pengapian)

11 OTO.KR02.010.01 (Memelihara/Servis Sistem Pendingin dan Komponen-komponennya)

12 OTO.KR02.020.01 (Memelihara/Servis Sistem Kontrol Emisi)

13 OTO.KR05.012.01 (Memelihara / Servis dan Memperbaiki Engine Manajemen sistem)

\section{Total}

Nilai Tertinggi

Nilai Terendah

Rata-rata

Standar Deviasi

$\begin{array}{cc}6 & 20.00 \\ 9 & 30.00 \\ & \\ 11 & 36.67 \\ & \\ 13 & 43.33 \\ 17 & 56.67 \\ 17 & 56.67 \\ 18 & 60.00 \\ 18 & 60.00 \\ 23 & 76.67 \\ - & - \\ 23 & 76,67 \\ 4 & 13,33 \\ 10,75 & 35,83 \\ 6,38 & 21,27\end{array}$

Berdasarkan hasil penelitian diketahui bahwa pada skema 03 (Servis dan Pemeliharaan 10.000 Km Kendaraan Ringan Injeksi) dari 13 unit kompetensi, unit kompetensi yang paling banyak dinyatakan belum kompeten adalah unit kompetensi dengan kode OTO.KR05.012.01 (Memelihara / Servis dan Memperbaiki Engine Manajemen Sistem) yaitu sebesar 76,67\% (23) peserta. Hal ini menunjukan bahwa pada unit kompetensi tersebut, sebanyak 76,67\% (23) peserta tidak dapat menunjukan kemahirannya dalam melaksanakan tugas yang berkaitan dengan unit kompetensi tersebut. Peserta tidak dapat menunjukan hasil yang sesuai dengan Kriteria Unjuk Kerja (KUK) yang dipersyaratkan.

Data menunjukan sebanyak 76,67\% (23) peserta dinyatakan belum kompeten karena tidak dapat memelihara / servis dan memperbaiki engine manajemen sistem sesuai dengan standar meliputi: (1) melaksanakan perbaikan komponen sistem bahan bakar bensin tanpa menyebabkan kerusakan terhadap komponen atau sistem lainnya, (2) mengakses dan memahami informasi engine manajemen sistim yang benar dari spesifikasi pabrik, (3) melaksanakan pengujian pada injeksi bahan bakar secara elektronik dan engine manajemen sistem untuk menentukan kesalahan / kerusakan dengan menggunakan peralatan dan tehnik yang sesuai, (4) melaksanakan pemeliharaan/servis, perbaikan, penggantian komponen dan penyetelan dengan menggunakan peralatan, teknik dan material yang sesuai, (5) melaksanakan seluruh kegiatan pemeliharaan/servis dan perbaikan berdasarkan SOP (Standard Operation Procedures), undang-undang K3 (Keselamatan dan Kesehatan Kerja), peraturan perundang-undangan dan prosedur/kebijakan perusahaan sehingga peserta dinyatakan belum kompeten. 
Berdasarkan analisis reportsheet yang termasuk dimensi kompetensi Taks Skill (TS) antara lain: (1) memeriksa kondisi EFI main relay dengan multitester, (2) memeriksa tahanan Throttle Potision Sensor (TPS), (3) memeriksa tahanan NE Sensor/CKP Sensor , (4) memeriksa tahanan Injector nomor 1,2,3 dan 4, (5) memeriksa tahanan Water Temperature Sensor (WTS), (6) memeriksa tahanan Intake Air Temperature Sensor (IATS), (7) memeriksa kondisi kendaraan dengan cara membaca trouble code pada scanner, (8) memeriksa kondisi mesin dengan membaca current data (WTS, IATS, Injector Signal (durasi injeksi), dan Sudut Pengapian). Selanjutnya dimensi Taks Management Skill (TMS) diukur ketika peserta uji kompetensi diharuskan menyelesaikan beberapa pekerjaan dalam satu waktu, waktu yang disediakan dibuat sedemikian rupa sehingga hanya cukup untuk mengerjakan pekerjaan yang diberikan yaitu memeriksa kondisi berbagai sensor pada mesin sekaligus dengan scanner tidak satu-satu. Jika peserta tidak dapat mengelola beberapa pekerjaan dalam waktu yang bersamaan maka peserta belum kompeten. Dimensi Contingency Management Skills (CMS) dilakukan dengan cara simulasi kejadian tidak lazim oleh asesor seperti misalnya kertas print scanner tidak keluar, atau kertas keluar namun tidak keluar tulisannya, dapat juga asesor memberikan pertanyaan kasus mengenai apa yang dilakukan peserta uji ketika jika ketika memeriksa current data tiba-tiba mesin mati atau kabel OBD2 terputus. Dimensi Job Role/Enviroment Skills (JRES) yaitu pada saat peserta uji melakukan pekerjaan dengan memperhatikan lingkungan kerja, standar kerja (spesifikasi teknis), atau Standard Operational Procedure (SOP) pekerjaan yang ada. Transfer Skills (TRS) diukur ketika peserta uji dapat melakukan pengukuran dengan menggunakan berbagai macam alat yang disediakan dan berbagai jenis kendaraan yang ada. Artinya, peserta uji dapat mentransfer kemampuannya kepada objek pekerjaan lain yang sejenis. Diagram sebaran unit kompetensi dapat dilihat pada gambar di bawah ini. 


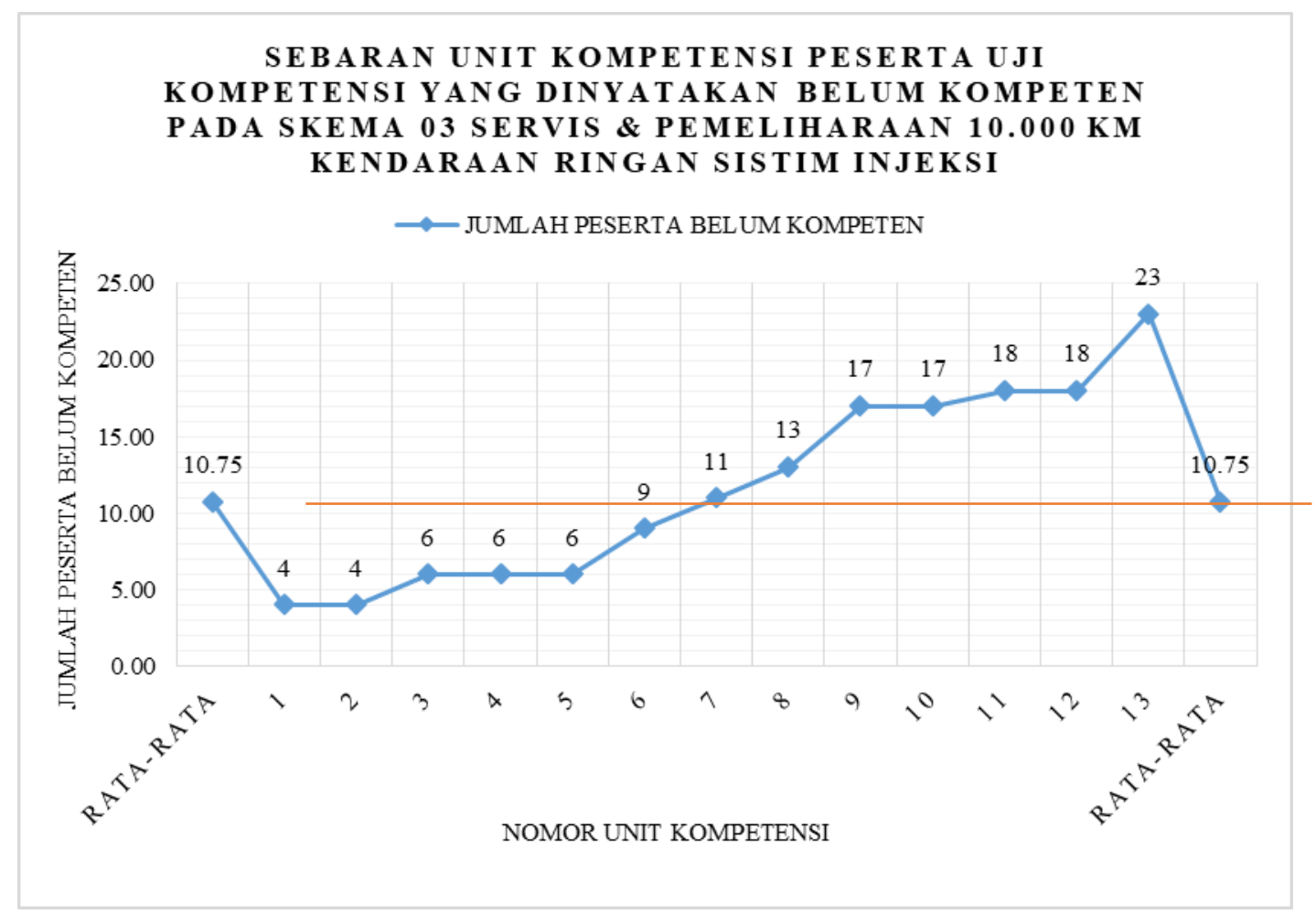

Gambar 3. Diagram Garis Sebaran Unit Kompetensi Peserta Uji Kompetensi yang Dinyatakan Belum Kompeten pada Skema 03 Servis dan Pemeliharaan 10.000 Km Kendaraan Ringan Sistim Injeksi

Sebaran unit kompetensi menunjukan kompetensi seseorang dalam melakukan suatu pekerjaan. Kompetensi dibentuk oleh kurikulum dari lembaga pendidikan dan pelatihan. Kompetensi harus senantiasa dipelihara dan disesuaikan dengan kebutuhan dan harapan perkembangan Dunia Usaha/ Dunia Industri (DUDI) termasuk pada pengembangan kurikulum yang diajarkan di sekolah sebagaimana hasil penelitian Gunadi, et.al (2014) yang menyatakan bahwa kompetensi yang diharapkan sekolah dan DUDI guna pengembangan kurikulum 2013 antara lain: mengukur dan menganalisis emisi kendaraan, menganalisis kerusakan pada sistem wiring diagram, serta melakukan diagnosa kerusakan.

Dalam rangka mencapai kompetensi, ada beberapa hal yang perlu diperhatikan sebagaimana hasil penelitian Santiyadnya (2011) yaitu antara lain: perkembangan teknologi, pasar kerja, pertambahan penduduk, perubahan pola kerja, konsep keunggulan lokal, sarana prasarana, jumlah dan mutu guru.

Menurut hasil penelitian Wibowo (2016) menyebutkan bahwa dalam menyiapkan tenaga kerja yang kompeten sesuai harapan industri, SMK dapat melaksanakan programprogram kegiatan yaitu: (1) program teaching factory; (2) Jalinan kerjasama dengan industri yang berbentuk: pengelolaan prakerin yang baik, on the job training (magang), pengelolaan 
kunjungan industri, rekruitmen tenaga kerja, penyelenggaraan kelas industri; dan (3) Penyuluhan dan pembinaan dari stake holder terkait dengan ketenagakerjaan.

\section{SIMPULAN DAN SARAN}

\section{Simpulan}

Berdasarkan hasil penelitian dapat disimpulkan bahwa:

1. Hasil uji kompetensi peserta uji kompetensi dari Daerah Istimewa Yogyakarta di LSP Otomotif Indonesia pada Tahun 2017 jika ditinjau berdasarkan skema 01 (Service \& Pemeliharaan 5000 KM Sepeda Motor) adalah sebanyak 70\% (70) peserta dinyatakan kompeten dan 30\% (30) peserta dinyatakan belum kompeten (termasuk kategori tinggi), selanjutnya pada skema 02 (Servis dan Pemeliharaan $10.000 \mathrm{Km}$ Kendaraan Ringan Konvensional) sebanyak 75\% (15) peserta dinyatakan kompeten dan 25\% (5) dinyatakan belum kompeten (termasuk kategori tinggi), dan pada skema 03 (Servis dan Pemeliharaan 10.000 Km Kendaraan Ringan Sistim Injeksi) sebanyak 61,54\% (48) peserta dinyatakan kompeten dan 38,46\% (30) dinyatakan belum kompeten (termasuk kategori sangat rendah),

2. Sebaran unit kompetensi peserta uji kompetensi menunjukan bahwa pada skema 01, unit kompetensi yang pesertanya paling banyak belum kompeten adalah OTO.SM02.001.01 (Memelihara Engine berikut Komponen-komponennya) yaitu sebesar $73,33 \%$, pada skema 02 unit kompetensi yang pesertanya paling banyak belum kompeten adalah OTO.KR02.014.01 (Memelihara/Servis Sistem Bahan Bakar Bensin) dan OTO.KR05.011.01 (Memperbaiki Sistem Pengapian) yaitu sama-sama sebesar $100 \%$, sedangkan pada skema 03 unit kompetensi yang pesertanya paling banyak belum kompeten adalah OTO.KR05.012.01 (Memelihara / Servis dan Memperbaiki Engine Manajemen sistem) yaitu sebesar 76,67\%.

\section{Saran}

Berdasarkan hasil penelitian penelitian peserta yang dinyatakan kompeten telah memiliki kemampuan mencakup aspek pengetahuan, keterampilan, dan sikap kerja sesuai SKKNI. Peserta yang dinyatakan kompeten akan mendapatkan sertifikat kompetensi dari BNSP yang merupakan pengakuan secara tertulis dari BNSP untuk meningkatkan pendapatan. 
Peserta uji kompetensi yang dinyatakan belum kompeten menunjukan bahwa mereka belum terampil dalam bekerja (belum sesuai standar), belum mampu melaksanakan tugastugas sesuai dengan elemen kompetensi dan kriteria unjuk kerja yang dibutuhkan dunia kerja, sehingga tidak mendapatkan sertifikat kompetensi dari BNSP, hanya mendapat logsheet dari LSP. Hasil yang belum optimal menunjukan perlunya peningkatan pendidikan dan pelatihan di lembaga maupun instansi yang terkait dengan calon tenaga kerja maupun tenaga kerja yang belum kompeten.

Saran bagi peserta uji kompetensi sebaiknya memyiapkan diri dengan belajar dan berlatih dengan sungguh-sungguh di lembaga pendidikan dan pelatihan yang fokus pada unitunit kompetensi dan kriteria unjuk kerja yang sesuai dengan standar SKKNI.

Bagi lembaga pendidikan dan pelatihan sebaiknya penyiapkan kurikulum, dan rencana pembelajaran yang diajarkan sesuai dengan SKKNI dan materi uji kompetensi yang sesuai dengan dunia kerja. Selanjutnya menyiapkan pendidik yang berkompeten sesuai dengan bidang yang akan diujikan.

Bagi lembaga sertifikasi profesi sebaiknya terus melakukan analisis dan kaji ulang terhadap hasil uji kompetensi dan materi uji kompetensi agar kualitas uji kompetensi tetap terjaga.

Bagi peneliti selanjutnya sebaiknya melakukan penelitian lanjutan untuk mengetahui penyebab ketidaktercapaian kompetensi peserta uji kompetensi.

\section{DAFTAR PUSTAKA}

Dobson, G. (2003). A Guide to Writing Competency Based Training Materials. Commonwealth of Australia Published by National Volunteer Skills Centre, First Published $\quad 2003 . \quad$ Dctober dakses https://www.k4health.org/sites/default/files/Guide\%20to\%20Writing\%20Competency \%20Based\%20Training\%20Materials.pdf pada tanggal 23 April 2018.

Garcia-Barbero, M., (1998). How To Develop Educational Programmes For Health Professionals. Copenhagen, WHO Regional Office for Europe

Gunadi, Usman T., Nugraha, B.S. (2014). Identifikasi Kompetensi SMK Program Studi Otomotif dalam Rangka Implementasi Kebijakan Kurikulum 2013. Jurnal Pendidikan Teknologi dan Kejuruan, Volume 22, Nomor 2, Oktober 2014 hlm.155 
Rauner, F., Heinemann, L., Maurer, A., et.al. (2013). Competence Development and Assessment in TVET (COMET). New York: Springer

Santiyadnya, N. (2011). Implementasi Uji Kompetensi dan Pengaruhnya Terhadap Kualitas Lulusan SMK Negeri Bidang Teknologi di Provinsi Bali. JPTK, UNDIKSHA, Vol. 8, No. 1, Januari 2011

Storey, L., Howard, J., Gillies, A. (2013). Competency in Healthcare "a Practical Guide to Competency Frameworks". Radcliffe Medical Press

Wibowo, N. (2016). Upaya Memperkecil Kesenjangan Kompetensi Lulusan Sekolah Menengah Kejuruan dengan Tuntutan Dunia Industri. Jurnal Pendidikan Teknologi dan Kejuruan, Volume 23, Nomor 1, Mei 2016 hlm.45

Wijanarka, B.S. (2008). Kesesuaian Materi Kompetensi Proses Pemesinan Terhadap Standar Kompetensi NIMS Pada Jurusan Pendidikan Teknik Mesin FT UNY. Jurnal Pendidikan Teknologi dan Kejuruan, Vol. 17, No.2, Oktober 2008. 